\title{
Wilhelm Schmid, Spokój ducha. Co zyskujemy z wiekiem [Gelassenheit. Was wir gewinnen, wenn wir älter werden], translated by Barbara Niedźwiecka, Wydawnictwo W.A.B., Warszawa 2017, p. 128
}

It would seem that old age is a time in a person's life which appears slowly, although noticeably, and at a fairly regular pace. Like the autumn, which in a sense announces itself by a vague feeling that the crescendo of nature, so pleasant to the eye, will finally have to stop, because it is impossible to listen to the end of the composition the dynamics of which is unbearably increasing, without resting even after reaching the climax.

The first yellowed leaf falling from a tree is calming and troubling at the same time. It calms because it introduces a counterpoint which breaks the melody, the one pleasant to the ear, yet already heard. It is frightening because, after all, its appearance is a sign that the musical theme will one day be exhausted, and together with it the end of the song will come.

The experience of Seneca, one of the ancient theorists and promoters of ars senescendi, the "art of ageing", seems to contradict this. In his XII Letter to Lucius, he describes an episode from his life when he arrived at his suburban estate after a long period of absence. Noticing that the sycamores surrounding his house had lost all their leaves, he reproved the steward for neglecting to look after the property. The latter, swearing first on his own guardian deity, was to answer Seneca calmly that it was not the lack of care for the trees that led to their miserable condition but the fact that they were already old. 
"And so", the Roman philosopher concludes this inconspicuous event with a fond recollection of the time of his youth, when he planted these trees, "I owe it to my suburban estate that my old age was shown to me wherever I went". It was a turning point, which, while stepping invisibly into the daily reality of his life, divided it into two periods of past youth and the newly discovered old age. This discovery, although surprising, did not seem painful to Seneca in any way, as the philosopher adds immediately afterwards: "Let us welcome it [old age - D.W.] kindly and love it. Because it, too, is full of charm, if you can take advantage of it".

Wilhelm Schmid (born 1953), a German philosopher and historian, lecturer at the University of Erfurt, writes his monograph in a similar manner, continuing the ars senescendi cultivated by ancient people such as Seneca or Cicero. The title of the publication itself, Peace of mind. What we gain with age, published by the W.A.B. Publishing House, suggests presenting old age as a positive phenomenon rather than, as it is commonly believed, especially in the times of the cult of youth, as an undesirable side effect of the laws of nature. The last stage of a person's life, which either ought to or has to be hidden from oneself and the world, counteracting in fact the awareness that the end is inevitably approaching. "Old age", as Schmid writes, "has been considered worthless, something that must be stopped by all available means" (p. 13).

To the contemporary Anti-Aging attitude, characterized by an almost programmatic aversion to the "static" and "powerless" old age, the German philosopher offers the Art of Aging, a kind of philosophical reflection on old age (cf. p. 11). However, before we discuss Schmid's attitude towards senectus, it is necessary to say something at this point about his attitude towards philosophy itself, which will slightly explain the way in which the author discusses the issue in question.

The German philosopher defines himself as a thinker practicing nothing else than the philosophy of the art of life (Lebenskunstphilosophie), thus placing himself on the side of the continuators of a long tradition that originated in ancient Greek and Roman philosophy (Gr. téchne tou bíou, téchne peri bion, Lat. ars vitae, ars vivendi), the various trends of which tried to formulate practical guidelines for achieving the state of eudaemony. In modern times, the subject of the art of life was raised by, among others, Pierre Hadot and Michel Foucault. Schmid's main inspiration is especially the work of the latter, 
who, especially in his late writings, searched for new forms of life to enable the subject to exist beyond the established concepts of being a subject.

Similar topics have been raised especially in the last four works of the philosopher: Myth sich selbst befreundet sein [Befriend yourself] (2004), Glück und Unglücklichsein [Happiness and unhappiness] (2007), Liebe [Love] (2010), Gelassenheit [Peace of mind] (2014). Apart from the last one, which is the subject of this review, none of them has been translated into Polish so far.

In an attempt to capture the essence of old age, Schmid tries above all to discover its cultural meaning. He is convinced that what defines it to the highest degree contradicts the ideals of modern Western societies. This is what the title "peace of mind" (Gelassenheit) stands for. The word is derived from the Middle High German language and was taken by the philosopher from Master Eckhart. This term was used by the aforementioned theologian and philosopher from the turn of the 13th and 14th centuries (later also by other representatives of Rhineland mysticism) to mean nothing more than "devotion to God" (cf. p. 14-15).

However, the German philosopher clearly emphasizes that the pursuit of peace of mind and soul has been valued by philosophers since ancient times. The Stoics and Epicureans paid a lot of attention to ataraxia, the state of a certain internal balance and imperturbability, which they presented as the ideal of human existence. References to both of these thought trends appeared many times in later eras.

Nowadays - as Schmid points out with nostalgia, but without unnecessary lecturing and defeatism - what can be noticed is a clear change in cultural patterns. The place of the variously understood "peace" as the goal of human aspirations is more and more often occupied by commonly approved dynamic and superficial feistiness which results in pettiness and quietism rather than conscious and responsible existence. "Nowadays", writes the German philosopher referring to Gelassenheit, "this state has been forgotten. Restraint is no longer considered an advantage, people have become victims of turbulent activism and scientific and technical excitement. The place for true peace was taken by fake easiness and being cool [...]" (p. 15).

Even old age, a period in one's life which seems to be particularly predisposed to the abandonment of activities that are not conducive to the building of an internal balance, has "become turbulent, does not give us 
a sense of internal harmony" (p. 15). Schmid's book is therefore, in a way, an invitation to philosophical reflection - contrary to the tendencies for social depreciation of both the "old age" and the "peace", criticized by the philosopher - on what to fill the mature age with, so that it becomes a truly conscious existence, fully reflecting the assumptions of Lebenskunstphilosophie.

In the formal aspect, the book is divided into ten chapters. The theme of each of them is a reflection, in a truly Stoic spirit, on one aspect of old age, giving rise to a certain normative proposal which, if read in its entirety, constitutes a specific ethic of old age. However, these are not overbearing and rigorous imperatives, but rather helpful guidelines, which are at the same time the result of the author's philosophical reflections and personal experience. If we read them with a certain degree of trust in philosophy as a discipline still capable of saying something sensible in the matter of selfcreation of one's own subject, we will receive an original and interesting proposal from the field of philosophy of the art of living.

The first chapter of the book is a philosophical reflection on the subsequent stages of human life. Schmid divides human existence from the point of view of the physiological development into three (or four) quarters, attributing a separate symbolic meaning to each of them. He uses a rather vivid metaphor of the day, according to which the first quarter of life corresponds to the morning, carrying with it enthusiasm and faith in one's own potential. From the first quarter, one smoothly moves to the second. However, in the midday of life, i.e. around thirty, one starts to realize for the first time that the horizon of one's existence is limited, so that one's life plans must also take into account the pressure of time.

The second quarter is a very intense period, where the individual is saying goodbye to the guessing mode and what matters is what he or she really can do. It is then that one starts a family and develops a professional career. Old age is only considered a little later, between forty and fifty, at the halfway point of life. Along with the crisis of the middle age, the perspective gives way to a retrospective, with more days gone than the days left over. "At this stage of life", writes Schmid, "the one who is ready to accept the changes to come will achieve peace of mind" (p. 24). These include slowly depleting life energy reserves and reduced adaptability. 
The second chapter focuses on the third quarter of human life, when a person not so much begins to feel the approach of ageing, but slowly starts to confront the first symptoms of old age. The subject of this chapter is precisely the attempt to understand these symptoms, the acceptance of which (and not denying or rebellious negation) is to secure the Gelassenheit. It seems that Schmid is suggesting that when a person becomes aware of shrinking life's perspectives, he or she starts to appreciate the present moment more (cf. p. 29).

In fact, this stage, which falls in the period between the 50th and 75th years of human life, is internally differentiated. Its beginning, shortly after turning fifty, is characterized by the mid-life crisis, which is often quite dynamic. But it is also a time for enjoying the skills acquired throughout one's life. The slow decline in strength is compensated for by a stable routine, and the intellectual potential, which is not disturbed by the multitude of tasks typical for a young person, can be better used, which also results in making more thoughtful choices. Only at the end of this period, which now extends to the fourth quarter of life, "the bubble of immortality breaks" (p. 32), physical signs of old age deepen, health deteriorates, infirmity progresses, until finally all skills are eroded.

When writing about the hardships of old age, Schmid does not want to present it as a period in the life of an individual which, before finally giving him or her up to death, slowly strips him or her of dignity and everything the person had achieved and believed in life. On the contrary, if one remembers about ageing while remaining in harmony with oneself and others, it is quite possible that one will reach and use old age in a creative way, full of inner peace.

Schmid called the advice, which was also a kind of philosophical reminder of how to achieve happy old age, ten steps (the first two of them, "reflection on the next stages of life" and "understanding the symptoms of old age" were discussed in the introduction to the book). They partly resemble the recommendations of ancient philosophers, yet this does not deprive them of their originality. What, then, according to the German thinker, should a person who wants to take advantage of one's own old age do?

Schmid, when describing step three, urges us to free ourselves from the tyranny of choice and to engage in routine activities. "The habits form the 
ruts with which life goes on predictably, calmly and regularly" (p. 44). The next chapter stresses the importance of finding peace of mind in finding happiness in small pleasures, such as the joy of observing nature or listening to valuable music. In chapter five, on the other hand, we talk about dealing with pain and misery - about their acceptance and ability to endure them, but also about fighting and relieving them when they become unbearable. As the sixth step towards achieving peace of mind, Schmid mentions touching and a sense of closeness, appreciating not only their carnal but also their spiritual significance. In chapter seven, which is a kind of a continuation of the previous one, the German philosopher emphasizes the sense-forming role of love and friendship as well as the strengthening of family ties. He also stresses the importance of reconciliation. Step eight, presented in the next chapter, is a philosophical invitation to reflect consciously on one's own life, since, in one's youth, there was often not enough time for this.

The last two chapters deal with attitudes towards death (chapter nine) and possible life after death (chapter ten). Schmid understands the end of life as a condition for the value of life. "The time limit granted", writes the philosopher, "motivates the effort to make life more valuable [...]" (p. 109). Thinking about death, as Schmid mentions, has been almost a philosophical exercise since Pythagoras' times. Looking at oneself from the perspective of an imaginary last minute, even if probably quite distant, is the ninth step towards achieving inner peace, according to Schmid.

Finally, and this is the tenth and final step, it is the daily familiarization with the idea that "you can feel safe in infinity - no matter what it is called" (p. 119). And also: "opening one's existence to the infinite dimension that is revealed after crossing the boundary of a finite life, or at least imagining the existence of such a dimension" (p. 120). Schmid does not impose any concrete eschatological vision but invites us, again in the Stoic spirit, to reflect on our own end, even if there is nothing more to come and to constantly confront it.

There seem to be few similar publications today that would subject a certain area of human praxis, which undoubtedly is old age, to philosophical reflection. This niche has been filled (rightly or not) by the so-called selfhelp literature, which, if addressing the subject matter in question, reduces it to offering advice on how to combat the visible symptoms of old age and 
thus postpone ageing itself. In such an approach, ars senescendi has no great chance of finding creative imitators.

Schmid's work, which cannot be excluded, stems from the social need to deal with a certain paradox that has given birth to contemporary times, namely the progressive improvement of social, living and health conditions (and, consequently, of the larger number of people living to the third and fourth quarters of their lives), while at the same time eliminating any references to old age in the public sphere. In his monograph, which is the subject of this review, Schmid tries to free old age imprisoned in nursing homes and hospices and to restore its social context. At the same time, he gives much valuable advice, supported by the authority of philosophy and his own thoughts, on how to approach the Gelassenheit, peace of mind. Critics may argue that these guidelines, such as maintaining friendships and appreciating small pleasures, are scandalously simple, if not trivial. But is wisdom not hidden in simplicity?

Dawid Winclaw Nicolaus Copernicus University, Toruń, Poland e-mail: dwinclaw@doktorant.umk.pl ORCID: 0000-0002-0738-4057 